\title{
Utilización de lodo seco de depuradora de aguas residuales como adición en adoquines de hormigón prefabricado
}

\section{Use of dry sludge from waste water treatment plants as an additive in prefabricated concrete bricks}

\author{
A. YAGÜE*, S. VALLS*, E. VÁZQUEZ*, V. KUCHINOW** \\ (*) Dept. Ingeniería de la Construcción, Universitat Politècnica de Catalunya, ETSECCPB, Barcelona \\ (“) UBENA, BBS, S.L ., Barcelona
}

Fecha de recepción: 26-XI-01

Fecha de aceptación: 18-XII-02

ESPAÑA

\section{RESUMEN}

El estudio ha consistido en la utilización de lodo seco de origen biológico de la depuradora de aguas residuales de Sabadell (Riu Sec), como adición en la preparación de adoquines de hormigón prefabricado.

Después de caracterizar los lodos y el proceso de fabricación de los adoquines que utilizaremos, definimos las condiciones de adición de los lodos en esta fabricación. Se prepararon muestras de referencia, sin adición, y muestras con el $2 \%$ de lodo seco sobre peso de cemento. Se determinaron cómo variaban en el tiempo, con la presencia de lodos: la densidad, la porosidad y el coeficiente de absorción, y la resistencia mecánica a compresión de los adoquines. También se determinó la lixiviación que estas piezas presentaban de acuerdo a la norma NEN 7345.

La adición de lodos produce, en la mayoría de los casos, una disminución de las porosidades y de los coeficientes de absorción y un aumento en las resistencias mecánicas, por lo que cabe esperar una mayor durabilidad de estos adoquines. En cuanto a la concentración de los contaminantes lixiviables en los adoquines, se encuentran por debajo del limite de la norma holandesa NEN, para la inclusión de residuos en matrices cimentantes y en consecuencia, se pueden clasificar como materiales inertes.
SUMMARY:

Dry sludge from the Sabadell Water Treatment Plant was used to prepare prefabricated concrete bricks.

After characterising the sludge and the manufacturing process used to make the bricks, we define the conditions of addition of the sludges in the manufacture. Reference samples not containing sludge and samples containing $2 \%$ of dry sludge by cement weight were prepared. The variation in density, porosity, absorption coefficient and compressive strength of the bricks with the presence of sludge was determined over time. Leaching of the bricks was determined according to the NEN 7345 standard.

In most cases the addition of sludge produces a decrease in porosity and absorption coefficients and an increase in compressive strength, so one could expect these bricks to have greater durability. As regards leaching pollutants in the bricks they are below the limit of the Dutch NEN standard for construction materials and thus can be classified as inert material.

KEYWORDS: dry sludge, waste water, prefabricated concrete, physical properties, mechanical properties, environmental impact, leaching

\section{INTRODUCTION}

Dry sludges from waste water treatment plants are produced in great quantities. Only in Catalonia it is calculated that between 600.000 and one million tons per year are produced. They concentrate most of the 
toneladas/año, en los que está concentrada la mayor parte de los contaminantes de las aguas, y para los que se habrían de buscar aplicaciones que los revaloricen y faciliten su reutilización.

Existen diversas aplicaciones para estos lodos que pueden permitir su reutilización: en la restauración de canteras, en terrenos marginales y en la agricultura (1). No obstante, estas aplicaciones no permiten reutilizar todos los lodos que se producen a lo largo de la vida útil de las depuradoras.

En el trabajo de Valls (1999) se constata la posibilidad de utilizar lodos húmedos en bases y subbases de carreteras con un ligante hidráulico como el cemento Portland (2).

Para disminuir la cantidad final de lodos producidos en algunas plantas se ha añadido una línea de secado, con lo que el producto final ya no es el lodo húmedo, sino seco. Los lodos, húmedos o secos, contienen la mayor parte de los contaminantes de las aguas residuales, principalmente metales pesados $\mathrm{y}$, en consecuencia, su utilización ha de ser controlada para evitar la contaminación de las zonas en que se usa.

Por ello, la adición de pequeñas cantidades de lodos en morteros y hormigones de cemento Portland permitirá, por una parte, diluir el residuo y, por otra, estabilizar estos metales que quedarán englobados en la matriz cimentante producida por la hidratación del cemento Portland.

Otro factor positivo para la eliminación de los iones de los metales pesados es el elevado $\mathrm{pH}(12-13)$ que se obtiene en el proceso de hidratación del cemento, que facilita su insolubilización por precipitación de los hidróxidos de estos metales y adsorción en la superficie de los hidratos formados.

A la vista de esta nueva situación nos planteamos la posible utilización de lodos secos. Éstos tienen más facilidades de uso que los húmedos, pues son de más fácil manipulación, los microorganismos que pudieran contener se han eliminado en el secado y, por todo ello, los procesos de putrefacción de la materia orgánica se han eliminado parcial o totalmente.

En anteriores trabajos de este equipo investigador se observaba que la mezcla con cemento estabilizaba los lodos húmedos, los cuales son más activos. En consecuencia, y con más motivo, se estabilizarán los lodos secos $\mathrm{y}$, de esta forma, se conseguirá inertizarlos y reutilizarlos (1-4). No obstante, en dichos trabajos se constato que la adición de lodos producía un retraso en los tiempos de inicio y final de fraguado y una disminución de las resistencias mecánicas, sobre todo a corto plazo. water pollutants, so it would be interesting to find applications to reuse and recycle them.

There are several applications for this sludge that enable it to be recycled, such as its use in restoring quarries, in wasteland and in agriculture (1). However, these applications can not use all the sludge that is produced during the useful life of a waste water treatment plant.

Walls (1999) states that wet sludge can be used in road bases and sub-bases with a hydraulic binder such as Portland cement (2).

To reduce the final amount of sludge produced in some plants, a drying line has been added so that the final product is not wet sludge but dry sludge. Wet or dry sludge contains most of the pollutants from waste waters -mainly heavy metals- and consequently, its use must be controlled to avoid polluting the areas in which it is employed.

The addition of small amounts of sludge to Portland cement mortars and concrete enables the waste to be diluted and these metals to be stabilised as they are fixed within the matrix produced by the hydration of the Portland cement.

Another positive factor for the elimination of the heavy metal ions is the high $\mathrm{pH}(12-13)$ that is obtained in the cement hydration process, facilitating insolubilisation by precipitation of the metal hydroxides and adsorption on the surface of the hydrates that are formed.

In view of this new situation, we consider the possible use of dry sludge. It is easy to handle that wet sludge because the microorganisms that it contains have been eliminated in the drying process, so the putrefaction process of the organic material has been partially or totally eliminated.

Previous work done by our research team found that mixing with cement stabilised wet sludge, which is more active, so dry sludge will certainly be stabilised and thus made inert and successfully recycled (1-4). However, this work also showed that the addition of sludge produced a delay in the beginning and the end of setting and a decrease in the mechanical resistance, especially in the short term. 
En este trabajo realizado con la colaboración de la Junta de Aguas de la Generalitat de Catalunya y las empresas: UBENA e ICA, se planteó la posibilidad de realizar una prueba piloto a escala industrial, añadiendo una pequeña proporción de lodos secos, en adoquines de hormigón prefabricado, y estudiar cómo varían las propiedades físicas y mecánicas de éstos. Se decidió que la adición fuera pequeña, $2 \%$ de lodo sobre peso de cemento, y se intentó no introducir alteraciones importantes sobre su proceso de fabricación.

\section{CARACTERIZACIÓN DEL LODO}

El lodo utilizado es un lodo biológico de secado térmico procedente de la depuradora de aguas residuales de Sabadell (Riu Sec). La caracterización del lodo ha consistido en: un análisis granulométrico, una caracterización química $(\mathrm{pH}$, porcentaje de materia orgánica, elementos químicos mayoritarios y lixiviación) y finalmente en una caracterización mineralógica, con el objetivo de determinar la fracción inorgánica cristalina del lodo.

\subsection{Caracterización granulométrica}

Hemos de tener en cuenta que el residuo, cl lodo, es añadido como una adición en un material de construcción en una matriz cimentante como el cemento Portland. Por ello, es necesario hacer una valoración de la fracción granulométrica del residuo una vez molturado mediante un molino mandíbulas, ver tabla 1.

Si comparamos la granulometria del lodo seco y de la arena utilizada en la planta de hormigones prefabricados, como la de la empresa ICA, ver tabla 1, se observa que el lodo es más fino. Si la granulometria de la arena utilizada en la empresa ICA y la del lodo las comparamos con los husos granulometricos para áridos finos que recomienda la EHE-1999 (5), el lodo es más fino y la arena entra dentro de los husos correspondientes.
In this work we collaborated with the Junta de Sanejament of the Generalitat (government) of Catalonia and the companies: UBENA and ICA. We decided to carry out a pilot test on an industrial scale by adding $a$ small proportion of dry sludge to prefabricated cement bricks and studying how the physical and mechanical properties of the bricks varied.

The amount of additive was small, $2 \%$ of sludge compared to the weight of the cement, and we tried not introduce major changes in the manufacturing process.

\section{CHARACTERISATION OF THE SLUDGE}

The sludge used was a thermally dried biological sludge from the Sabadell Sewage Treatment Plant (Riu Sec). The characterisation of the sludge consisted of: a granulometric analysis; a chemical characterisation ( $\mathrm{pH}$, percentage of organic matter, predominant, chemical elements and leaching); and finally, a mineralogical characterisation to determine the crystalline inorganic fraction of the sludge.

\subsection{Granulometric characterisation}

We should take into account the fact that the waste, the sludge, is an additive to a building material with a binding matrix such as Portland cement. The granulometric fraction of the waste must therefore be assessed once it has been ground using a jaw grinder (see table 1).

If we compare the granulometry of the dry sludge and that of sand used in prefabricated concrete, such as that used by the ICA company (see table 1), it is seen that the sludge is finer. If the granulometry of the sand used in the ICA company and that of the sludge is compared with the grading envelopes for fine aggregates recommended by the EHE-1999 (5) Standard, the sludge is finer and the sand falls within the corresponding envelopes.

TABLA $1 / T A B L E I$

A nálisis granulométrico del lodo

(Granulometric analysis of the sludge)

\begin{tabular}{|c|c|c|c|}
\hline $\begin{array}{c}\text { Tamiz } \\
(\mathrm{mm}) / \text { Sieve } \\
(\mathrm{mm})\end{array}$ & $\begin{array}{c}\text { \% Pasa lodo } \\
\text { (\% Sludge } \\
\text { passing) }\end{array}$ & $\begin{array}{c}\text { \% Pasa arena-ICA } \\
(\% \text { Sand passing-IC) }\end{array}$ & $\begin{array}{c}\text { Huso granulometrico } \\
\text { (Grading envelope })\end{array}$ \\
\hline 5 & 100 & 97 & 100 \\
\hline 4 & 99 & 97 & $100-80$ \\
\hline 2 & 96 & 81.4 & $96-62$ \\
\hline 1 & 91.4 & 55.9 & $84-39.7$ \\
\hline 0.5 & 74.9 & 45.1 & $60-18$ \\
\hline 0.25 & 44.4 & 26.5 & $30-6$ \\
\hline 0.125 & 14 & 12.8 & $18-0$ \\
\hline 0.074 & 4.2 & 3.7 & $1-0$ \\
\hline
\end{tabular}




\subsection{Caracterización química}

En las tablas 2, 3, 4 y 5 se expresan los resultados de la caracterización química del lodo seco de Sabadell (Riu $\mathrm{Sec})$.

\subsection{Chemical characterization}

Tables 2, 3, 4 and 5 show results for the chemical characterization of the dry sludge from Sabadell (Riu $\mathrm{Sec}$ ).

TABLA $2 / T A B L E 2$

Caracterización del lodo seco procedente de la depuradora de Sabadell (Characterization of the dry sludge from the Sabadell treatment plant)

\begin{tabular}{|c|c|}
\hline $\mathrm{pH}$ & 7.08 \\
\hline Pérdida a $105{ }^{\circ} \mathrm{C}\left(\right.$ Loss at $\left.105{ }^{\circ} \mathrm{C}\right)$ & $19 \%$ \\
\hline $\begin{array}{c}\text { Materia orgánica a } 500^{\circ} \mathrm{C} /(\text { Organic } \\
\left.\text { matter at } 500{ }^{\circ} \mathrm{C}\right)\end{array}$ & $41.5-52 \%$ \\
\hline
\end{tabular}

TABLA $3 / T A B L E 3$

Elementos mayoritarios del lodo seco-Sabadell por fluorescencia de Rayos X (Main elements of Sabadell dry sludge determined by X-Ray)

\begin{tabular}{|l|l|l|l|}
\hline $\mathrm{Na}_{2} \mathrm{O}$ & $1.11 \pm 0.07 \%$ & $\mathrm{CaO}$ & $22.7 \pm 0.2 \%$ \\
\hline $\mathrm{MgO}$ & $2.73 \pm 0.08 \%$ & $\mathrm{Cr}_{2} \mathrm{O}_{3}$ & $0.24 \pm 0.02 \%$ \\
\hline $\mathrm{A}_{2} \mathrm{O}_{3}$ & $12.9 \pm 0.2 \%$ & $\mathrm{Fe}_{2} \mathrm{O}_{3}$ & $10.1 \pm 0.1 \%$ \\
\hline $\mathrm{SiO}_{2}$ & $29.7 \pm 0.2 \%$ & $\mathrm{NiO}$ & $0.13 \pm 0.01 \%$ \\
\hline $\mathrm{P}_{2} \mathrm{O}_{5}$ & $12.4 \pm 0.2 \%$ & $\mathrm{CuO}$ & $0.23 \pm 0.02 \%$ \\
\hline $\mathrm{SO}_{3}$ & $3.22 \pm 0.08 \%$ & $\mathrm{ZnO}$ & $0.84 \pm 0.04 \%$ \\
\hline $\mathrm{Cl}_{2} \mathrm{O}$ & $0.20 \pm 0.01 \%$ & $\mathrm{SrO}$ & $0.29 \pm 0.02 \%$ \\
\hline & $1.83 \pm 0.06 \%$ & $\mathrm{ZrO}_{2}$ & $0.16 \pm 0.01 \%$ \\
\hline
\end{tabular}

T A B L A $4 / T A B L E 4$

Resultado de la concentración de metales pesados en mg/ldel lodo seco Sabadell por el ensayo de la lixiviación DIN 38414-S4, y los limites de concentración

(Results of the heavy metal concentration of Sabadell dry lode in $\mathrm{mg} / \mathrm{l}$ by the DIN $38414-S 4$ leaching test, and the concentration limits)

\begin{tabular}{|c|c|c|c|c|c|c|c|}
\hline \multirow[t]{2}{*}{$\begin{array}{l}\text { Metales } \\
\text { (Metals) }\end{array}$} & \multirow[t]{2}{*}{$\begin{array}{c}\text { Concentración } \\
\mathrm{m} / \mathrm{l} \\
(\text { Concentration } \\
m \mathrm{~g} / \mathrm{l})\end{array}$} & \multicolumn{2}{|c|}{$\begin{array}{c}\text { Limite D IN } \\
38414-\mathrm{S} 4 \\
(\text { Limit D IN } \\
38414-S 4)\end{array}$} & \multirow[t]{2}{*}{$\begin{array}{l}\text { M etales } \\
\text { (Metals) }\end{array}$} & \multirow[t]{2}{*}{$\begin{array}{c}\text { Concentración } \\
\mathrm{mg} / \mathrm{l} \\
\text { (Concentration } \\
m \mathrm{~g} / \mathrm{l} \text { ) }\end{array}$} & \multicolumn{2}{|c|}{$\begin{array}{c}\text { Limite D IN } \\
38414-S 4 \\
(L \text { im it DIN } \\
38414-S 4)\end{array}$} \\
\hline & & $\mathrm{A}$ & $\mathrm{B}$ & & & $\mathrm{A}$ & $\mathrm{B}$ \\
\hline $\mathrm{Ba}$ & $0.109 \pm 0.0005$ & $-\cdots$ & -- & $\mathrm{Mn}$ & $0.23 \pm 0.01$ & $\overline{-\cdots}$ & $\ldots$ \\
\hline $\mathrm{Zn}$ & $0.68 \pm 0.03$ & 2 & 5 & $\mathrm{Cd}$ & $<0.01$ & 0.1 & 0.2 \\
\hline $\mathrm{Ni}$ & $1.058 \pm 0.003$ & 0.5 & 1 & $\mathrm{Cr}$ & $0.05 \pm 0.01$ & 0.1 & 0.1 \\
\hline $\mathrm{Pb}$ & $<0.05$ & 0.5 & 1 & $\mathrm{As}$ & $<0.1$ & 0.1 & 0.5 \\
\hline $\mathrm{Cu}$ & $0.31 \pm 0.07$ & 2 & 5 & & & & \\
\hline
\end{tabular}

TAB L A $5 / T A B L E 5$

Resultados de la lixiviación del lodo de Sabadell (Riu Sec) según NEN-7341, lixiviación de disponibilidad

(Results of the leaching of the Sabadell (Riu Sec) sludge according to NEN-7341, availability leaching)

\begin{tabular}{|c|c|c|c|c|c|}
\hline $\begin{array}{l}\text { Mi etales } \\
\text { (Metals) }\end{array}$ & $\begin{array}{c}\text { Concentración } \\
\mathrm{m} g / 1 \\
\text { (Concentration } \\
m g / l)\end{array}$ & $\begin{array}{l}\text { Concentración } \\
\text { mg/kg de } \\
\text { muestra seca } \\
\text { (Concentration } \\
\text { mg/kgdry } \\
\text { sample) }\end{array}$ & $\begin{array}{l}\text { M etales } \\
\text { (Metals) }\end{array}$ & $\begin{array}{c}\text { Concentración } \\
\mathrm{m} \mathrm{g} / \mathrm{l} \\
(\text { Concentration } \\
m \mathrm{~g} / \mathrm{l})\end{array}$ & $\begin{array}{c}\text { Concentración } \\
\text { mg/kg de } \\
\text { muestra seca } \\
\text { (Concentration } \\
\text { mg/kg dry } \\
\text { sample) }\end{array}$ \\
\hline $\mathrm{B}$ a & $0.75 \pm 0.001$ & $5.45 \pm 0.03$ & $\mathrm{M} \mathrm{n}$ & $0.8 \pm 0.1$ & $39 \pm 6$ \\
\hline $\mathrm{Zn}$ & $1.23 \pm 0.06$ & $34 \pm 1$ & $\mathrm{Cd}$ & $<0.01$ & $<0.5$ \\
\hline $\mathrm{Ni}$ & $1.69 \pm 0.05$ & $85 \pm 3$ & $\mathrm{Cr}$ & $0.09 \pm 0.01$ & $4.8 \pm 0.6$ \\
\hline $\mathrm{Pb}$ & $<0.05$ & $<2.5$ & A s & $<0.1$ & $<5$ \\
\hline $\mathrm{Cu}$ & $.0 .57 \pm 0.04$ & $29 \pm 2$ & & & \\
\hline
\end{tabular}


En el Decreto 34/1996 del 9 de enero de 1996 (7) de la Generalitat de Catalunya, en el que se aprobó el catalogo de residuos, éstos se clasifican según los valores de los parámetros sobre el lixiviado obtenido por el ensayo de lixiviación DIN 38414-S4 (6). Según el resultado de la lixiviación DIN 38414-S4, el lodo seco de la depuradora de Sabadell, es un residuo especial, ya que su concentración en el elemento níquel, aunque, por muy poco, supera el límite B de la norma.

Una vez clasificado el lodo según el catalogo de Residuos de la Generalitat de Catalunya, es conveniente también conocer los metales pesados lixiviables del residuo según un método más agresivo, como es el ensayo de lixiviación holandés NEN 7341 (8), ensayo de disponibilidad, el cual permite posteriormente valorar el porcentaje de fijación de los contaminantes por parte de la matriz cementante, ver tabla 5 .

\subsection{Caracterización mineralógica}

Para identificar la composición inorgánica cristalina del lodo se ha realizado un análisis de difracción de rayos $\mathrm{X}$. Su composición mineral es cuarzo y calcita, dos minerales que no conllevan a ningún problema de expansión al mezclarlos con el cemento Portland. El lodo no presenta ningún mineral del tipo arcilloso que podría incrementar la demanda de agua en la mezcla $y$, a su vez, dar problemas de expansión.

\section{LOS ADOQUINES: CARACTERIZACIÓN Y PROCESO DE FABRICACIÓN}

Para que la adición de lodo en la preparación de los adoquines prefabricados de ICA, pudiese ser de interés industrial nos planteamos, como condición necesaria, que el proceso de adición del lodo tuviese una incidencia mínima en el proceso de fabricación de los adoquines, ya que si era necesario variar el proceso de fabricación sus posibilidades reales de uso serian nulas. En consecuencia, los lodos se adicionaron junto a la arena sin alterar el normal proceso industrial. La prueba piloto se realizó en las instalaciones de ICA en la localidad de Sant Andreu de la Barca, Barcelona.

El lodo se mezcla con la arena y posteriormente se amasa con el cemento, durante el tiempo estipulado para el proceso de fabricación de las piezas en cuestión por la empresa ICA. Después se llenan los moldes y se compactan enérgicamente los adoquines. Los adoquines del modelo VÍA VERDE, que fue el modelo elegido, están constituidos por dos capas: una, que forma la mayor parte del adoquín en la que se ha añadido el lodo, y una fina capa superficial de acabado, que se amasa por separado, a la que no hemos añadido lodo. La consistencia seca de la mezcla y la intensa compactación a que están sometidas, hace que las piezas se puedan desmoldear inmediatamente después de la compactación para entrar a continuación en las cámaras de curado.
Decree 34/1996 of the Generalitat of Catalonia, of $9^{\text {th }}$ january 1996 (7) approved a catalogue of waste, which was classified according to values of leaching obtained by the DIN 38414-S4 (6) leaching test. According to the DIN 38414-S4 (6) leaching test, the dry sludge from the Sabadell treatment plant is a special case because the concentrations of nickel are very slightly above limit $B$ of the standard.

In addition to the classification of the sludge, in accordance with the Government of Catalonia's Wastes Catalogue, it is also important to know the leachable heavy metals available by using a more aggressive method such as the Dutch NEN 7341 leaching test (8), an availability test which measures the percentage of fixing of the pollutants by the binding matrix; see table 5 .

\subsection{Mineralogical characterization}

To identify the inorganic crystalline composition of the sludge, $x$-ray diffraction analyses were carried out. The mineral composition is made up of quartz and calcite, two minerals that do not involve any expansion problems when they are mixed with a binding matrix such as Portland cement. There is no clay-like mineral in the sludge, which could increase water requirements in the mixture, and, therefore, cause expansion problems.

\section{THE BRICKS: CHARACTERIZATION AND MANUFACTURING PROCESS}

For the addition of the sludge, in the preparation of prefabricated bricks at the ICA factory, a necessary condition was that the sludge addition process should have the least possible effects on the manufacturing process. If the manufacturing process had to be altered, then the likelihood of sludge being used were practically nil. The sludge was thus added together with the sand without changing the normal industrial process. The pilot test was carried out at the ICA plant in Sant Andreu de la Barca, Barcelona.

The sludge was mixed with sand and subsequently with cement for the time stipulated for the ICA brick manufacturing process. The moulds were then filled and the bricks were pressed. The bricks of the model VÍA VERDE, which were chosen for the test, are composed of two layers: one that makes up the body of the brick, in which the sludge was added, and a thin surface layer, which gives the finish to the brick and was mixed separately without sludge. The dry consistency of the mix and the intense compacting to which it was submitted meant that the pieces could be taken out of the moulds immediately after pressing and moved to the drying chambers. The trays with shaped bricks were automatically transported to a nearby area where they were cured. 
En la prueba piloto no se apreciaron diferencias ni en la preparación, ni en el aspecto, entre la amasada de referencia y las que contenían un $2 \%$ de lodo como adición respecto al peso de cemento.

Las características del proceso industrial de fabricación de estos adoquines hace que los adoquines de una misma bandeja no sean idénticos entre sí. Los técnicos de ICA, que conocen a fondo su proceso de producción, propusieron que el estudio se realizara con adoquines que en cada bandeja ocuparan las mismas posiciones relativas, de tal forma que sus condiciones de fabricación fueran lo más semejantes posibles.

Escogimos ocho posiciones en cada bandeja e identificamos los adoquines con un número, del 1 al 8 , y un subíndice $\mathrm{N}, 1$ o 2 según se tratara de la amasada de referencia o de las dos amasadas realizadas ambas con un $2 \%$ de lodo.

Proyectamos realizar un control a lo largo del tiempo de: densidad, porosidad y absorción de los adoquines, resistencia mecánica a la compresión y lixiviación.

En total el número de adoquines ensayados fue de tres muestras por cada posición por ocho posiciones por tres amasadas (72 adoquines).

El resto de adoquines con lodo se colocaron, junto a adoquines sin adición en la depuradora de Valls para observar su evolución in situ.

\section{METODOLOGÍA Y RESULTADOS}

\subsection{Densidad, porosidad y absorción a diferentes edades}

A 28 días se ha determinado la densidad, porosidad y absorción de los adoquines según la norma UNE 10973:1999 (9) y se han obtenido los siguientes resultados a 28 días y 1 año, ver tablas 6 y 7 .

De los resultados a 28 días podemos comprobar que las densidades prácticamente no varían con la pequeña adición de lodos. Pero en cuanto a la porosidad y la absorción, la adición de lodo hace disminuir estos valores, por lo que hay que esperar una mejor durabilidad de los adoquines con lodo.

A 1 año observamos que en lo que se refiere a la densidad de los adcquines los valores prácticamente no varían, como sucedía a 28 días.

Para la porosidad y la absorción destacar que la presencia de lodos hace que los valores para los adoquines con adición sean, en el peor de los casos, ligeramente superiores al de referencia y en el resto tienen valores inferiores al de referencia.
In the pilot test no differences in preparation or in appearance were perceived between the reference mix and that containing $2 \%$ of sludge to cement weight.

The characteristics of the industrial brick manufacturing process meant that bricks from the same tray were not identical. ICA technicians, who were extremely well acquainted with their production process, proposed that the study was carried out by placing the bricks in the same relative position on the different trays so that their manufacturing conditions were as similar as possible.

Eight positions on each tray were chosen and we identified the bricks with a number, from 1 to 8 , and a subindex $N, 1$ or 2 according to whether it was the reference mix or the two mixes with $2 \%$ sludge content.

A long-term control was set up: density, porosity and absorption of the bricks, compressive strength and leaching

The number of bricks tested was a total of 3 samples for each of the eight positions on the tray by three mixes (72 bricks).

The rest of the bricks containing sludge were placed next to bricks without sludge at the Valls treatment plant so that their evolution could be observed in situ.

\section{METHODOLOGY AND RESULTS}

\subsection{Density, porosity and absorption at different ages}

The density, porosity and absorption of the bricks were observed according to the 1097-3:1999 UNE Standard (9) and the following results were obtained at 28 days and one year (see tables 6 and 7).

From the results at 28 days it is seen that the densities hardly vary with small additions of sludge. However, the addition of sludge decreases porosity and absorption, so bricks containing sludge can be expected to have greater durability.

At 1 year the density values of the bricks are practically the same as these at 28 days.

The porosity and absorption values of bricks with sludge are in the worst cases slightly higher than those of the reference bricks and in the rest lower, so bricks with sludge can be expected to have greater durability. 
Si comparamos entre sí los valores a 28 días y a 1 año observamos que, como era de esperar por la progresiva hidratación del cemento en el hormigón, las porosidades y las absorciones disminuyen al aumentar la edad del hormigón.

Respecto a densidades sus valores son muy semejantes en todos los tipos de adoquines.

\subsection{Resistencia mecánica a la compresión a diferentes edades}

Para les resistencias a compresión se cortaron probetas cúbicas de $7 \mathrm{~cm}$ de lado de los adoquines fabricados. Rompiéndose a compresión a las edades de 28 días y 1 año, ver tablas 8 y 9 .
If the values at 28 days are compared with those at 1 year, it is seen that the porosity and absorption decrease as the age of the concrete increases, as would be expected due to the progressive hydration of the cement in the concrete.

The densities are very similar in all types of bricks.

\subsection{Compressive strength at different ages}

To test the compressive strength, cubic samples of 7 $\mathrm{cm}$ were cut from the bricks. Compressive strength at the ages of 28 days and 1 year (see tables 8 and 9).

TABLA 6/TABLE 6

Densidad, porosidad y absorción a 28 días, de los adoquines 1 y 4 , de las posiciones de la bandeja (Density, porosity and absorption at 28 days, the simples 1 and 4)

\begin{tabular}{|c|c|c|c|c|c|}
\hline $\begin{array}{c}\text { Muestra } \\
\text { (Sample) }\end{array}$ & $\begin{array}{c}\text { Densidad } \\
\text { Aparente } \\
\text { (Apparent } \\
\text { Density) }\end{array}$ & $\begin{array}{c}\text { Densidad } \\
\text { Real } \\
\text { (Real } \\
\text { Density) }\end{array}$ & $\begin{array}{c}\text { Porosidad } \\
\text { Aparente } \\
\text { Apparent } \\
\text { Density) }\end{array}$ & $\begin{array}{c}\text { Porosidad } \\
\text { Real } \\
\text { (Real } \\
\text { Porosity) }\end{array}$ & $\begin{array}{c}\text { Absorción } \\
\text { Absorption) }\end{array}$ \\
\hline $1_{\mathrm{N}}$ & 2.2 & 2.5 & 14.9 & 17.3 & 6.9 \\
\hline $1_{1}$ & 2.2 & 2.5 & 12.6 & 14.4 & 5.8 \\
\hline $1_{2}$ & 2.2 & 2.5 & 12.2 & 13.9 & 5.6 \\
\hline $4_{\mathrm{N}}$ & 2.2 & 2.5 & 14.5 & 17.0 & 6.7 \\
\hline $4_{1}$ & 2.2 & 2.5 & 13.3 & 15.3 & 6.2 \\
\hline $4_{2}$ & 2.1 & 2.5 & 13.7 & 15.9 & 6.5 \\
\hline
\end{tabular}

TABLA 7/TABLE 7

Densidad, porosidad y absorción a 1 año, de los adoquines 6 y 7, de las posiciones de la bandeja

(Density, porosity and absorption at 1 year, the simples 6 and 7)

\begin{tabular}{|c|c|c|c|c|c|}
\hline $\begin{array}{c}\text { Muestra } \\
\text { (Sample) }\end{array}$ & $\begin{array}{c}\text { Densidad } \\
\text { Aparente } \\
\text { (Apparent } \\
\text { Density) }\end{array}$ & $\begin{array}{c}\text { Densidad } \\
\text { Real } \\
\text { (Real } \\
\text { Density) }\end{array}$ & $\begin{array}{c}\text { Porosidad } \\
\text { Aparente } \\
\text { Apparent } \\
\text { Density) }\end{array}$ & $\begin{array}{c}\text { Porosidad } \\
\text { Real } \\
\text { (Real } \\
\text { Porosity) }\end{array}$ & $\begin{array}{c}\text { Absorción } \\
\text { (Absorption) }\end{array}$ \\
\hline $6_{\mathrm{N}}$ & 2.2 & 2.5 & 11.9 & 13.5 & 5.5 \\
\hline $6_{1}$ & 2.2 & 2.5 & 12.3 & 13.9 & 5.7 \\
\hline $6_{2}$ & 2.2 & 2.5 & 11.5 & 13.0 & 5.3 \\
\hline $7_{\mathrm{N}}$ & 2.2 & 2.5 & 12.8 & 14.7 & 5.9 \\
\hline $7_{1}$ & 2.2 & 2.5 & 10.3 & 11.5 & 4.7 \\
\hline $7_{2}$ & 2.2 & 2.5 & 11.6 & 13.1 & 5.3 \\
\hline
\end{tabular}

TABLA 8/TABLE 8

Resistencia a compresión (MPa) a 28 días de las muestras en la posición 1 y 4 de la bandeja (Compressive strength (MPa) at 28 days))

\begin{tabular}{|c|c|}
\hline $\begin{array}{c}\text { Muestra } \\
\text { (Sample) }\end{array}$ & $\begin{array}{c}\text { Resistencia Compresión } \\
\text { (Compressive Strength) }\end{array}$ \\
\hline $1_{\mathrm{N}}$ & 38,6 \\
\hline $1_{1}$ & 36,7 \\
\hline $1_{2}$ & 34,4 \\
\hline $4_{\mathrm{N}}$ & 30,3 \\
\hline $4_{1}$ & 37,0 \\
\hline $4_{2}$ & 33,4 \\
\hline
\end{tabular}


Resistencia a compresión (MPa) a 1 año de las muestras en la posición 6 y 7 de la bandeja

(Compressive strength (MPa) at 1 year))

\begin{tabular}{|c|c|}
\hline $\begin{array}{c}\text { Muestra } \\
\text { (Sample) }\end{array}$ & $\begin{array}{c}\text { Resistencia Compresión } \\
\text { (Compressive Strength) }\end{array}$ \\
\hline $6_{\mathrm{N}}$ & 45,2 \\
\hline $6_{1}$ & 53,7 \\
\hline $6_{2}$ & 44,6 \\
\hline $7_{\mathrm{N}}$ & 45,2 \\
\hline $7_{1}$ & 45,9 \\
\hline $7_{2}$ & 47,6 \\
\hline
\end{tabular}

Se observa que las resistencias mecánicas a compresión, tanto a 28 días como a 1 año son elevadas, y que las series con lodos alcanzan, como mínimo, valores del mismo orden de resistencia que las de referencia y, en bastantes casos, su resistencia es mayor que la de éstas. Como era de suponer, las resistencias son mayores a 1 año en todos los casos y no se detecta ningún problema en los adoquines con lodos.

\section{VALORACIÓN DEL IMPACTO MEDIOAMBIENTAL}

La valoración de la calidad medioambiental del producto elaborado y la garantía de su uso en la construcción, requiere que se cumplan una serie de requisitos, entre los cuales la necesidad de que los eluatos que se extraigan por acción del agua, estén libres de contaminantes, o bien que las concentraciones de los mismos estén por debajo de ciertos límites establecidos. Para ello, se requiere de la realización de unos ensayos de lixiviación. Actualmente, en España no existen normas reglamentarias sobre la evaluación ambiental de los materiales de construcción, pero sí en ciertos países europeos como Holanda, (Netherlands Tank Leaching Test (NTLT)).

\subsection{Proceso de lixiviación en los materiales de construcción}

\subsubsection{Ensayo de lixiviación NEN 7345}

En Europa se han desarrollado varios tipos de test de lixiviación de tipo monolítico para evaluar el potencial y la velocidad de lixiviación de matrices con residuos estabilizados a largo plazo. El más utilizado es el test holandés, Netherlands Tank Leaching Test (NTLT). Según la clasificación de tipos de tests de lixiviación de carácter especifico, el test NEN-7345 es un test de velocidad de migración (10). Se calcula la lixiviación acumulativa en $\mathrm{mg} / \mathrm{m}^{2}$ para cada uno de los contaminantes de un total de 8 extracciones durante 64 días.
It is seen that compressive strength is high both at 28 days and 1 year and that the series containing sludge reaches the same order of values as the reference bricks, and in many cases higher values. As was to be expected, the strength was higher at 1 year in all cases and no problems were found in the bricks containing sludge.

\section{ENVIRONMENTAL IMPACT ASSESSMENT}

The assessment of the environmental quality of the manufactured product and the guarantee of its use in building require a series of conditions to be fulfilled. The eluates extracted due to the action of water must be free of pollutants and their concentrations must be below certain established limits. This requires leaching tests to be carried out. At present, there are no official standards on the environmental assessment of construction materials in Spain. However, in other European countries such as Holland these do exist (the Netherlands Tank Leaching Test, NTLT).

\subsection{The leaching process in construction materials}

\subsubsection{The NEN 7345 leaching test}

Various types of monolithic leaching tests have been developed in Europe to assess the long-term potential and rate of leaching in matrices with l stabilised waste products. The most common is the Dutch test, the Netherlands Tank Leaching Test (NTLT). According to the type classification of specific leaching tests, the NEN7345 test is a migration rate test (10). The cumulative leaching in $\mathrm{mg} / \mathrm{m}^{2}$ for each pollutant is calculated from a total of 8 extractions during 64 days. 
La Legislación Holandesa (NEN 7345) según los valores de lixiviación acumulativa obtenidos en los lixiviados clasifica los materiales en tres categorías. La categoría 1 corresponde a un material que no presenta ninguna restricción medioambiental para su utilización. La categoría 2 tampoco presentan ninguna restricción medioambiental para su uso, pero se obliga a la extracción del contaminante que supera el límite inferior al acabar la vida útil del material. Y la categoría 3 los valores de lixiviación acumulativa están por encima del límite superior y en este caso los materiales tienen una utilización restringida

\subsubsection{Resultados}

En este proceso de lixiviación acumulativo $\left(\mathrm{mg} / \mathrm{m}^{2}\right)$ del material ensayado se han considerado los contaminantes siguientes: $\mathrm{Ba}, \mathrm{Cd}, \mathrm{Mn}, \mathrm{Cr}, \mathrm{Cu}, \mathrm{Ni}$, $\mathrm{Pb}, \mathrm{Zn}$, As contemplados en la normativa holandesa.

Del total de muestras obtenidas en la fabricación, se han ensayo dos muestras con sus triplicados, dos de las muestras son hormigones de referencia sin inclusión de lodo seco y las dos restantes con inclusión de lodo en un $2 \%$ del peso de cemento. El resultado obtenido en cada muestra viene expresado en la siguiente tabla 10 .

Para valorar el grado de fijación por parte de la matriz cementante, cemento Portland, de los contaminantes tóxicos, se ha comparado los resultados extraídos de la lixiviación de disponibilidad (NEN 7341) en el residuo con los de
The Dutch Legislation (NEN 7345) classifies materials into three categories according to the leaching values obtained. Category 1 corresponds to material that can be used without any environmental restriction. Category 2 can also be used without environmental restrictions, but the pollutant that exceeds the lower limit must be extracted at the end of the material's useful life. In Category 3, the cumulative leaching values are above the upper limit, and in this case, the use of the materials is restricted.

\subsubsection{Results}

In the cumulative leaching process $\left(\mathrm{mg} / \mathrm{m}^{2}\right)$ of the tested material, the following pollutants were considered using Dutch standards: $\mathrm{Ba}, \mathrm{Cd}, \mathrm{Mn}, \mathrm{Cr}, \mathrm{Cu}, \mathrm{Ni}, \mathrm{Pb}, \mathrm{Zn}$.

From all the samples obtained during manufacture, two of them were tested together with their duplicates. Two of the samples were reference concretes without dry sludge and the remaining two contained $2 \%$ sludge by cement weight. The results obtained in each sample are shown in table 10.

In order to evaluate the degree of fixing of toxic pollutants by the binding, Portland cement matrix, the results obtained from the availability leaching test (NEN 7341) were compared with those of the

TABLA $10 / T A B L E 10$

Concentración de metales pesados $\left(\mathrm{mg} / \mathrm{m}^{2}\right)$ en los adoquines estudiados según norma NEN -7345 (Heavy metal concentration $\left(\mathrm{mg} / \mathrm{m}^{2}\right)$ in bricks studied as per the NEN-7345 standard))

\begin{tabular}{|c|c|c|c|c|c|}
\hline $\begin{array}{c}\text { Metal } \\
\text { (Metals) }\end{array}$ & $\begin{array}{c}\text { Muestra/Sample } \\
1_{\mathrm{N} .1}\end{array}$ & $\begin{array}{c}\text { Muestra/Sample } \\
1_{\mathrm{N} .2}\end{array}$ & $\begin{array}{c}\text { Muestra/Sample } \\
4_{1.1} \\
(2 \% \text { lodo })\end{array}$ & $\begin{array}{c}\text { Muestra/Sample } \\
4_{1.2} \\
(2 \% \text { lodo })\end{array}$ & $\begin{array}{c}\text { Límite/Limit } \\
\mathrm{U}_{1}\end{array}$ \\
\hline $\mathrm{Pb}$ & $<2.95$ & $<3.17$ & $<3.33$ & $<3.31$ & 100 \\
\hline $\mathrm{Zinc}$ & $2.30 \pm 0.02$ & $2.12 \pm 0.05$ & $4.70 \pm 0.12$ & $4.56 \pm 0.22$ & 200 \\
\hline $\mathrm{Ni}$ & $<1.47$ & $<1.60$ & $<1.67$ & $<1.60$ & 50 \\
\hline $\mathrm{Cr}$ & $<0.59$ & $<0.61$ & 1.53 & 1.8 & 150 \\
\hline $\mathrm{Cu}$ & $<0.29$ & $<0,32$ & $<0.33$ & $<0.33$ & 50 \\
\hline $\mathrm{Cd}$ & $<0.29$ & $<0.32$ & $<0.33$ & $<0.33$ & 1 \\
\hline $\mathrm{Ba}$ & $<0.66$ & $<0.63$ & 0.80 & 0.83 & 600 \\
\hline $\mathrm{Mn}$ & $1.47 \pm 0.13$ & $1.52 \pm 0.011$ & $2.12 \pm 0.082$ & $2.16 \pm 0.06$ & --- \\
\hline $\mathrm{As}$ & $<5.90$ & $<6.35$ & $<6.67$ & $<6.62$ & 40 \\
\hline
\end{tabular}


la lixiviación monolítica (NEN 7345), los resultados quedan reflejados en la tabla 11.

cementante es del orden del 70 al $76 \%$, correspondiente al contaminante cromo.

El porcentaje de fijación mínima por parte de la matriz monolithic leaching test (NEN 7345). The results are shown in table 11.

The lowest percentage of fixing by the binding matrix, which corresponds to the pollutant chromium, is of $70 \%$ to $76 \%$.

TABLE 11/TABLE 11

Porcentaje de fijación de los metales pesados detectables por la técnica de Plasma Inducción (ICP), en la matriz cementante, adoquines

(Percentage of fixing of heavy metals detectable by the Induction Plasma (ICP) technique, in the binding matrix, bricks)

\begin{tabular}{|c|c|c|}
\hline $\begin{array}{c}\text { Metales } \\
\text { (Metals) }\end{array}$ & $\begin{array}{c}\text { Muestra/Sample } 4_{1.1} \\
\text { (2\% lodo)/(2\% } \\
\text { sludge) }\end{array}$ & $\begin{array}{c}\text { Mucstra/Sample } 4_{1.2} \\
(2 \% \text { lodo }) /(2 \% \text { sludge })\end{array}$ \\
\hline $\mathrm{Zn}$ & $96.8 \%$ & $95.3 \%$ \\
\hline $\mathrm{Cr}$ & $75.8 \%$ & $70.6 \%$ \\
\hline $\mathrm{Ba}$ & $89.5 \%$ & $88.1 \%$ \\
\hline $\mathrm{Mn}$ & $95.3 \%$ & $95.6 \%$ \\
\hline
\end{tabular}

\section{CONCLUSIONES}

De los resultados anteriores se deduce que el comportamiento a corto y medio plazo de los adoquines con una adición de un $2 \%$ de lodo seco de la EDAR de Sabadell sobre peso de cemento en el hormigón, presentan unos resultados, desde el punto de vista de estas propiedades, que los hace aptos para su uso presentando unos valores del mismo orden y, en numerosos casos, mejores que los adoquines de referencia.

Además con esta proporción no ha sido necesario modificar el proceso de fabricación de los adoquines de ICA.

A la vista de los resultados obtenidos en los ensayos de lixiviación, se puede concluir que ningún adoquín con inclusión de lodo seco tiene restricción ambiental para su uso como material, estando todos situados por debajo del límite $\mathrm{U}_{1}$ de la norma holandesa NEN 7345 $\mathrm{y}$, en consecuencia, se pueden clasificar como material inerte. De la misma manera, se observa que el porcentaje de fijación por parte de la matriz cementante de los contaminantes es elevado, en el peor de los casos sólo se fija un $70 \%$ de cromo presente.

Podría ser interesante aumentar la proporción de lodo añadido, llegar a un valor del orden de un 4 o $5 \%$, y estudiar cómo varían estas propiedades.

\section{CONCLUSIONS}

From the above results, it is seen that the short-and medium-term behaviour of bricks with the addition of $2 \%$ dry sludge by cement weight, from the Sabadell water treatment plant, make them suitable for use, because they are of the same order and in many cases better than those of the reference bricks.

Furthermore, using this proportion it was not necessary to modify the brick manufacturing process at ICA.

In view of the leaching results, it may be concluded that none of the bricks containing dry sludge has any environmental restriction for its use as a construction material, as all of them are below the $U_{1}$ limit of the NEN Standard, and, consequently, can be classified as inert material. Likewise, it is observed that the percentage of fixing of pollutants by the binding matrix is high: in the worst cases, at least $70 \%$ of chromium is fixed.

It may be interesting to increase the proportion of added sludge to reach values of the order of 4 or $5 \%$ and to study how the properties vary. 


\section{BIBLIOGRAFÍA}

(1) Vázquez, E., Valls, S., Roca, A., Rovira, J., Aurin, R., Casado, A., Kuchinow, V., i Gassó, A. Material per bases i subbases de carretera amb llots de depuradora i enderrocs. Ponències de les Jornades sobre la Reutilització de Fangs de Depuració de Aigües Residuals Urbanes. Junta de Sanejament, Departament de Medi Ambient, Generalitat de Catalunya. Barcelona, 1996.

(2) Valls S. Estabilización física y química de los lodos de depuradora de aguas residuales y de material de demolición para su utilización en ingeniería civil, Tesis Doctoral, Julio de 1999, Barcelona.

(3) Valls S and Vázquez E. Stabilization and solidification of sewage sludges with Portland cement. Cement and Concrete Research, Vol. 30, n 10 pp. 1671-1678. Octubre, 2000.

(4) Yagüe A, Valls S, Vázquez E y Kuchinow.V. Study of hydration of cement pastes and dry sewage sludge. Proceedings of the International Symposium by the Recycling and Reuse of Sewage Sludge at the University of Dundee, Scotland, UK on 19-20 March 2001, pp.: 253-261.

(5) INSTRUCCIÓN DE HORMIGÓN ESTRUCTURAL. Ministerio de Fomento. Serie de normativas, Madrid, 1999.

(6) DIN 38414-S4. German Standard Procedure for Water, Wastewater and Sludge Analysis, Sludge and Sediment (Group S). Determination of water Leachability, Benthe-Vertrieb Gmbh, Berlin and Köln, Germany.

(7) DOGC. Decret Legislatiu 34/1996, del 9 de gener de 1996, Catàleg de Residuos de Catalunya. DOGC 2166 (9-2-1996).

(8) NEN 7341. Determination of leaching characteristics of inorganic components from granular waste materials. NNI, Delft (Netherlands). Formerly NVN 2508. (1993).

(9) ASOCIACION ESPAÑOLA DE NORMALIZACIÓN Y CERTIFICACION. Ensayos para determinar las propiedades mecánicas y fisicas de los áridos. Parte 3: Determinación de la densidad aparente y la porosidad. UNE 1097-3, Madrid, 1999.

(10) NEN 7345. Determination of the release of inorganic constituents from construction materials and stabilized waste products. NNI, Delft (Netherlands). Formerly Draft NEN 5432. 1993. 